\title{
The Influence of Emotional Quotient and Learning Behavior to Accounting Student's Understanding on Public Sector Accounting
}

\author{
Devy Sylvia Puspitasari ${ }^{1}$, Tituk Diah Widajantie ${ }^{2}$, Indrawati Yuhertiana ${ }^{3}$, Dyah Ratnawati ${ }^{4}$, \\ Tamadoy Thamrin ${ }^{5}$ \\ \{devy.puspitasari.ak@upnjatim.ac.id $\left.{ }^{1}\right\}$ \\ 1,2,3,4,5 Universitas Pembangunan Nasional "Veteran” Jawa Timur, Indonesia
}

\begin{abstract}
This study investigates the impact of psychological factor on college student understanding of public sector accounting. Accounting students of University of Pembangunan Nasional "Veteran" Jawa Timur as population. This study uses a mixed method with sequential explanatory design. There are 42 respondents who study public sector accounting as their concentration. Partial Least Square use to test two hyphoteses. The finding shows that emotional quotient and learning behaviour are significantly influence the understanding of public sector accounting subject.
\end{abstract}

Keywords: emotional quotient, learning behavior, understanding on public sector accounting

\section{Introduction}

The phenomenon of the industrial revolution era 4.0 is absolute and cannot be resisted. The industrial revolution 4.0 is marked by major changes in connectivity (sensor technology, the internet of things and mobile devices), intelligence (computing power, big data, image and speech recognition), and flexible automation [1]. The development of digital technology in addition to providing positive benefits in various fields, while increasing risks simultaneously. The Industrial Revolution 4.0 had a significant impact on the accounting profession and accounting students. Some of the impacts are the rapid flow of information, changes in people's views in obtaining information through internet technology, including in public sector accounting. Public sector accounting teaches accounting in the scope of public sector organizations. The intended public sector includes, for example, central and regional government organizations, Non-Governmental Organizations (NGOs), hospitals, and education. The most important thing in public sector organizations is the responsibility for where and for what sources of organization funding. So accounting graduates who are competent, have strategies, soft skills (interpersonal skills and intra-personal skills), and technical skills are needed to be able to answer the challenges in this digital age.

Performance professionalism is built based on soft skills and abilities possessed by employees. It can be built starting from the students in understanding each course. Educators must also prepare students with the mindset, adaptive nature, and flexibility because what they have learned will soon be different or change in this digital era. In addition, it takes a mentality and enthusiasm for learners and innovative to support these goals. [2] argues that soft skills contribute to organizational success. The level of interaction and soft skills of a person is called 
emotional intelligence (EQ). [3] states that the more emotionally intelligent a person is, the person can be categorized as successful with interesting, assertive, feeling better, and more comfortable communication than other people in the scope of work. The contribution of intelligence quotient (IQ) to a person's success is only about $20 \%$, the remaining $80 \%$ is determined by a factor called emotional intelligence [4]. Intellectual intelligence plays an important role for students in understanding public sector accounting, but it will not run well if it is not matched by the ability to manage emotions (EQ) themselves when faced with the problems of lecture learning.

The need for lifelong learning requires higher education to create independent learners [5]. Students who can divide the time of learning activities, carry out responsibilities is a form of good learning behavior. This behavior will influence learning achievement [6]. Students' abilities in starting and maintaining learning processes make a difference in learning success [7]. Research that focuses on individual aspects shows various factors that influence individual behavior in the world of work. Recent research focusing on individual behavior in public sector accounting is increasing ([8]; [9]; [10]; [11]) proving that psychological responses such as work pressure encourage individuals to perform dysfunctional behavior. The college is a place for learning and individual character formation to become a professional graduate accountant. The level of understanding of students in understanding public sector accounting is not only demonstrated through grades, but mastery of the concept of the course.

\section{Research Method}

This study uses a mixed method method with an explanatory sequential design, which is a mixed research method that starts with quantitative data collection then continues with qualitative data collection. Data collection techniques used are primary data by distributing questionnaires, then the data are analyzed using Partial Least Square (PLS). There are 42 respondents who study public sector accounting as their concentration. Then the qualitative method uses focused interviews with open-ended question guidance. The questionnaire was used to use a Likert scale to assess emotional quotient, learning behavior, and student understanding of public sector accounting. Data obtained from interviews, field notes and sound recordings are then analyzed by enriching information, looking for relationships, finding patterns on the basis of the original data. The results of data analysis are presented in the form of narrative descriptions.

There are three variables used in this study. Emotional quotient (X1): the ability of someone to manage their emotions with intelligence; the appropriateness of emotion and its expression through self-awareness skills, self-control, self-motivation, empathy and social skills [3]. Learning behavior (X2): learning is a process of adaptive behavior that is progressive, so there is significant progress in understanding it. Learning behavior is often also called learning habits, is a dimension of learning that individuals do repeatedly so that it becomes a habit. According to [12] learning behavior is measured based on the habit of following a lesson, the habit of reading a book, the habit of preparing a paper, the habit of facing an exam. Understanding of public sector accounting (Y): the level of one's ability to know and understand about public sector accounting. 


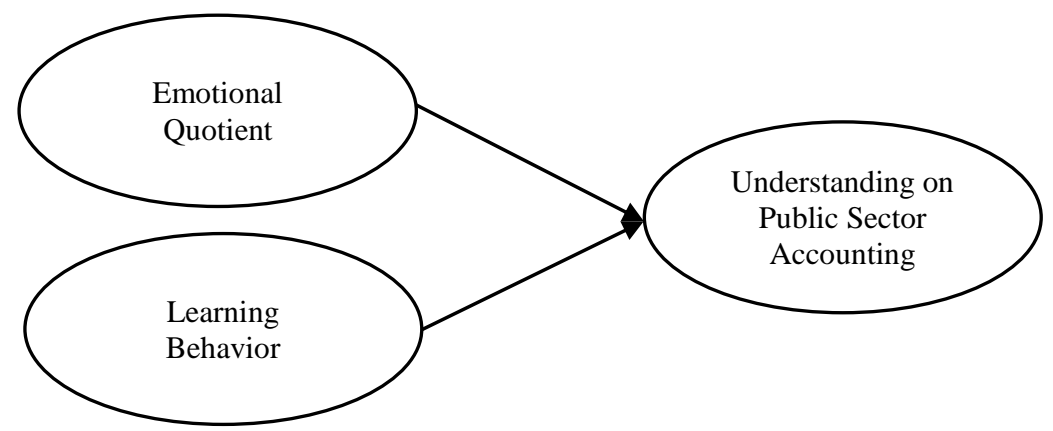

Fig. 1. Research Framework

\section{Result and Discussion}

The influence of emotional quotient on understanding on public sector accounting

Salovey \& Mayer (1990) states that emotions are organized responses, crossing psychological boundaries such as physiological, cognitive, motivational, and experiential systems. Emotional intelligence involves the ability to monitor the feelings and emotions of others. It is part of social intelligence to guide one's thinking and actions. The ability of individuals to utilize their emotions is useful for solving problems. When people implement their lives with emotional intelligence, they can solve problems in an adaptive manner. According to [3] the ability of a person to regulate his emotions with intelligence, maintain emotional appropriateness and disclosure through self-awareness skills, self-control, selfmotivation, empathy and social skills. It can be concluded that emotional intelligence is how an individual is able to form themselves to be more organized in regulating the feelings and emotions of others. For example, good relations with others, be it with lecturers or friends and can manage the emotions of yourself and others can improve understanding in accepting public sector accounting.

The results of testing of hypothesis 1 show that emotional intelligence has a significant effect on public sector accounting understanding. This means that the higher the emotional intelligence of the student, the higher the understanding he has. Thus the existing abilities can support a student to achieve his goals and ideals. Understanding of public sector accounting is influenced by emotional quotient and learning behavior by $39 \%$ (R-square), others are influenced by other factors not found in this model. The results of this study are consistent with research conducted by [13], [14]. Furthermore, the informant's statement supports the quantitative results that accounting whose valuation is identical to intellectual intelligence should be understood based on the heart in order to create a balance in understanding public sector accounting. Furthermore, lectures involving affective expertise related to the heart can internalize noble values in accounting. It can be concluded that a student with high emotional intelligence will have a positive impact to manage his feelings, be able to deal with frustration, be able to motivate himself, set a reactive mood, and be able to empathize and cooperate with others, so students can understand public sector accounting well . 
The influence of learning behavior on understanding on public sector accounting

Learning behavior in universities one of which can also determine the success or failure of a student in understanding accounting. [12] states that there are several aspects of learning in higher education, including: the meaning of lectures, the conception of lecturers, independence in learning, learning experiences or values, language skills and having books. Achievement is evidence of the success of the effort achieved [15]. It can be concluded that achievement can be achieved when students manage to manage the learning process that is well taken. Good learning behavior means a lot of time and concentration is given by students to understand public sector accounting. The results of testing of hypothesis 2 shows that learning behavior has a significant effect on public sector accounting understanding. This means that the better the student's learning behavior, the higher the understanding of public sector accounting. Understanding of public sector accounting is influenced by emotional quotient and learning behavior by $39 \%$ ( $\mathrm{R}$ square), others are influenced by other factors not found in this model. The results of this study are consistent with research conducted by [16], [17], [18]. Furthermore, the informant's statement supports the quantitative results that initiatives to learn before and after getting material can improve public sector accounting understanding. Learning methods are now growing, not only through face to face but students can also learn through online (e-learning). According to the informants, in this era of digitalization they are more able to motivate themselves by exploring knowledge through internet facilities, YouTube videos, and unlimited communication through e-learning. This can support students in capturing and understanding a material so that it can produce good academic achievement.

\section{Acknowledgement}

This research was supported by Accounting Major, Universitas Pembangunan Nasional "Veteran" Jawa Timur. The completion of this undertaking could not have been possible without the participation and assistance of so many people whose names may not all be enumerated. To all relatives, friends, and others who in one way or another shared their support, either morally, financially and physically. Above all, to the Great Almighty, the author of knowledge and wisdom, for this countless love. We thank you.

\section{References}

[1] World Economic Forum, "World economic forum and the fourth industrial revolution in South Africa," TRADE \& INDUSTRIAL POLICY STRATEGIES, 2018. [Online]. Available: http://www.dti.gov.za/industrial_development/docs/TIPS.pdf.

[2] D. D. Goleman, Emotional intelligence: Why it can matter more than IQ for character, health and lifelong achievement. 1995.

[3] D. Goleman, Emotional Intelligence : Kecerdasan emosional mengapa EI lebih penting daripada IQ. Jakarta: PT. Gramedia Pustaka Utama, 2015.

[4] D. Goleman, Kecerdasan emosi untuk mencapai puncak prestasi. Jakarta: PT. Gramedia Pustaka Utama, 2003.

[5] D. Nicol and D. MacFarlane-Dick, "Formative assessment and selfregulated learning: A model and seven principles of good feedback practice," Stud. High. Educ., vol. 31, no. 2, pp. 199-218, 2006.

[6] G. L. Cook, D. Bay, B. Visser, J. E. Myburgh, and J. Njoroge, "Emotional intelligence: The role of accounting education and work experience," Issues Account. Educ., vol. 26, 
no. 2, pp. 267-286, 2011.

[7] C. Schumacher and D. Ifenthaler, "Features students really expect from learning analytics," Comput. Human Behav., 2018.

[8] D. S. Puspitasari, A. Djamhuri, and I. Subekti, "Anggaran Partisipatif, Senjangan Anggaran, Kinerja Aparatur Pemerintah dan Tata Kelola Pemerintahan (Studi pada Pemerintah Daerah Kabupaten Malang),” J. Ilm. Adm. Publik, 2017.

[9] R. Rahma, I. Yuhertiana, and S. Sundari, "The use of E-audit in increasing government audit finding," J. Theor. Appl. Inf. Technol., 2016.

[10] F. Ardiyani, I. Yuhertiana, and G. S. Budiwitjaksono, "Psychological aspect of auditor and disfungsional conduct on the government budget supervision," Religacion, vol. 4, no. 17, pp. 593-598, 2019.

[11] N. M. Sani, I. Yuheriana, and D. Suhartini, "Participative budgeting, society culture, dysfunctional behavior and public satisfaction: in Sumenep District, Madura Island," Religacion, vol. 4, no. 17, pp. 581-591, 2019.

[12] Suwardjono, "Perilaku Belajar di Perguruan Tinggi," J. Akunt. Manaj., vol. Maret, 1991.

[13] A. R. J. Jayadi and L. Purwanti, "Pengaruh kecerdasan emosional dan perilaku belajar terhadap pemahaman akuntansi," J. Chem. Inf. Model., vol. 2, no. 1, 2013.

[14] F. B. A. R. Nugroho and D. Kristanto, "Pengaruh Kecerdasan Emosional, Kecerdasan Intelektual, Perilaku Belajar, Kompetensi Dosen dan Fasilitas Pembelajaran Terhadap Pemahaman Akuntansi," J. Akunt. dan Sist. Teknol. Inf., vol. 14, no. 2, pp. 351-360, 2018.

[15] W. S. Winkel, Psikologi pendidikan dan evaluasi belajar. Jakarta: PT. Gramedia Pustaka Utama, 1984.

[16] A. A. N. A. Kresnandra, "Pengaruh Perilaku Belajar terhadap Tingkat Pemahaman Akuntansi dengan Kecerdasan Emosional sebagai Variabel Pemoderasi,” E-Journal Akunt. Univ. Udayana, vol. 28, no. 3, pp. 2065-2075, 2019.

[17] S. A. Aulia, "Pengaruh Pengendalian Diri, Motivasi, dan Perilaku Belajar Terhadap Tingkat Pemahaman Akuntansi Mahasiswa," Econ. Educ. Anal. J., vol. 5, no. 1, pp. 346-362, 2016.

[18] L. A. Rokhana and S. Sutrisno, "Pengaruh Kecerdasan Emosional, Perilaku Belajar, dan Minat Belajar Terhadap Tingkat Pemahaman Akuntansi. (Studi Empiris pada Mahasiswa Akuntansi Fakultas Ekonomika dan Bisnis UNTAG Semarang)," Media Ekon. dan Manaj., vol. 31, no. 1, pp. 26-38, 2016. 